\title{
POTASSIUM SUPPLYING CAPACITY OF SOME LOWLAND SOILS UNDER POTASSIUM FERTILIZATION AND SUCCESSIVE CROPPINGS
}

\author{
CAPACIDADE DE SUPRIMENTO DE POTÁSSIO DE ALGUNS SOLOS DE VÁRZEA \\ SUBMETIDOS A ADUBAÇÃO POTÁSSICA E CULTIVOS SUCESSIVOS
}

\author{
Fábio STEINER ${ }^{1}$; Maria do Carmo LANA²; Tiago ZOZ'; Alan Mario ZUFFO' \\ 1. Department of Agronomy, State University of Mato Grosso do Sul, Cassilândia, MS, Brazil, steiner@uems.br. 2. Department of \\ Agronomy, State University of Western Paraná, Marechal Cândido Rondon, Paraná, Brazil.
}

\begin{abstract}
The effects of intense cropping and potassium fertilization on potassium (K) dynamics and non-exchangeable K release from three lowland soils of Paraná State, Brazil, were investigated in this study. Samples of three lowland soils were fertilized or not with $\mathrm{K}$ and subjected to six successive croppings (soybeans, pearl millet, wheat, common beans, soybeans, and maize). The crops were grown in 8-L pots for 45 days, and at the end of the sixth cropping, the soil from each pot was sampled to the determination of soil $\mathrm{K}$ pools. The lowland soils differ in the ability to $\mathrm{K}$ supply to the plants in the short to medium term due to the wide range of origin material and the concentration of $\mathrm{K}$ in solution, exchangeable $\mathrm{K}$, non-exchangeable $\mathrm{K}$, and structural $\mathrm{K}$. When the soils were not fertilized with $\mathrm{K}$, the successive cropping resulted in continuous depletion process of non-exchangeable and exchangeable K; however, this depletion was less pronounced in soils with a higher potential buffer capacity of K. Non-exchangeable and exchangeable K concentrations were increased with the addition of $\mathrm{K}$ fertilizer, indicating the occurrence of $\mathrm{K}$ fixation in soil. The non-exchangeable $\mathrm{K}$ contribution to $\mathrm{K}$ nutrition of plants ranged from 44 to $69 \%$ in the treatments without the addition of $\mathrm{K}$ fertilizer, reporting the importance of non-exchangeable $\mathrm{K}$ pools in the supply of this nutrient to plants in agricultural production systems.
\end{abstract}

KEYWORDS: Exchangeable K. Intense cropping. Non-exchangeable K. Soil potassium budget.

\section{INTRODUCTION}

Potassium $(\mathrm{K})$ is a macronutrient needed in large amounts by plants. Soil $\mathrm{K}$ includes the solution $\mathrm{K}$, exchangeable $\mathrm{K}$, non-exchangeable $\mathrm{K}$, and structural $\mathrm{K}$, and these pools are in equilibrium, following a gradient in which its availability decreases (BARBER, 1995). The existence of these various pools of soil $\mathrm{K}$ and its incessant transformation from one pool into another as well as the gain and losses generate a dynamic system in the soil. The most important component of this dynamics is soil mineralogy, including primary and secondary minerals (VELDE; PECK, 2002; SIMONSSON; HILLIER; ÖBORN, 2009). The status of different pools of $\mathrm{K}$ in the soil, their release characteristics and fixation are the other important components of K-dynamics (BILIAS; BARBAYIANNIS, 2018; STEINER; LANA, 2018), which in turn are regulated by the soil mineralogical makeup.

Potassium concentration in soil solution and as exchangeable $\mathrm{K}$ (readily available pools) is relatively low $(0.1$ to $2.0 \%$ of total $\mathrm{K})$ and corresponds to crop demand during only a few years of intense cropping (ROSOLEM; VICENTINI; STEINER, 2012; STEINER et al., 2015). When solution $\mathrm{K}$ and exchangeable $\mathrm{K}$ are reduced to low levels by plant uptake and/or leaching, nonexchangeable $\mathrm{K}$ can be released from clay interlayers and contribute significantly to plant $\mathrm{K}$ nutrition in some soils (ROSOLEM; VICENTINI; STEINER 2012; VIEIRA et al., 2016; BILIAS; BARBAYIANNIS, 2018). Therefore, for sustainable crop production, the available $\mathrm{K}$ must be continually replenished through non-exchangeable and mineral $\mathrm{K}$ reserves.

Soybean cultivation in lowland areas, where irrigated rice cultivation predominates, has increased in recent decades. However, this production environment differs from traditional soybean cultivation areas by presenting hydromorphic soils with low natural drainage, subject to excess moisture at some time during soybean development. In lowland soils, the reducing conditions caused by flooding resulting in a larger fraction of the $\mathrm{K}^{+}$ions being displaced from the exchange complex into the soil solution (BARBER, 1995). The release of a relatively large amount of iron $\left(\mathrm{Fe}^{2+}\right)$ and manganese $\left(\mathrm{Mn}^{2+}\right)$ ions and production of ammonium $\left(\mathrm{NH}_{4}^{+}\right)$ions result in the displacement of some of the $\mathrm{K}^{+}$ions from the exchange complex to the soil solution. This may lead to greater availability of $\mathrm{K}$ to rice in flooded 
soils, as reported by Fraga et al. (2009). This increased diffusion rate of $\mathrm{K}$ in the soil may result in the contribution from the structural $\mathrm{K}$ of feldspars and micas, and $\mathrm{K}$ retained in the interlayer of some 2:1 clay mineral. These pools are considered as nonexchangeable and can be an important source of this nutrient to plants (ROSOLEM; VICENTINI; STEINER, 2012; STEINER; LANA, 2018). Therefore, understanding the mechanisms that involve release and fixation of $\mathrm{K}$ in the soil is important because soils may contain widely variable pools of $\mathrm{K}$ that are potentially mobilized by chemical weathering of soil minerals (SIMONSSON; HILLIER; ÖBORN, 2009).

Rosolem, Machado, and Ribeiro (1988) found that when the exchangeable $\mathrm{K}$ concentration is less than $60 \mathrm{mg} \mathrm{kg}^{-1}$ there is the release of $\mathrm{K}$ from non-exchangeable sources, and these sources would be responsible for the $\mathrm{K}$ nutrition of plants, and the maintenance of appropriate levels of soil exchangeable K. In upland soils of Paraná, Brazil, Steiner and Lana (2018) reported that nonexchangeable $\mathrm{K}$ contribution to $\mathrm{K}$ nutrition of plants was up to $73 \%$ of $K$ taken up in a successive cropping system. In lowland soils of Rio Grande do Sul, Brazil, Fraga et al. (2009) concluded that nonexchangeable $\mathrm{K}$ contribution to the $\mathrm{K}$ nutrition of rice plants ranged 12 to $72 \%$ in the treatments no fertilized and fertilized with $\mathrm{K}$, respectively. Borkert et al. (1997) observed a marked decrease in soil exchangeable $\mathrm{K}$ concentration during successive years of soybean crops and reported that it would be necessary to apply at least $80 \mathrm{~kg} \mathrm{ha}^{-1} \mathrm{yr}^{-1}$ of $\mathrm{K}_{2} \mathrm{O}$ to maintain soil exchangeable $\mathrm{K}$ concentrations and avoid depletion of this nutrient soil reserves.

The contribution of non-exchangeable $\mathrm{K}$ to plant-available $\mathrm{K}^{+}$can be estimated by intensive cropping of plants in the pot (FRAGA et al., 2009; ROSOLEM; VICENTINI; STEINER, 2012; STEINER; LANA, 2018). However, it is unknown the contribution of these pools of $K$ on plant nutrition in the lowland soils of Paraná, Brazil. In this sense, this study aimed to evaluate the effects of intensive cropping and potassium fertilization on $\mathrm{K}$ dynamics and non-exchangeable $\mathrm{K}$ release from three lowland soils of Paraná State, Brazil.

\section{MATERIAL AND METHODS}

Pots experiments were carried out in greenhouse conditions in Marechal Cândido Rondon, Paraná, Brazil $\left(24^{\circ} 31^{\prime} \mathrm{S}, 54^{\circ} 01^{\prime} \mathrm{W}\right.$, and altitude of $420 \mathrm{~m}$ ) to study the effects of intense cropping and $\mathrm{K}$ fertilization on $\mathrm{K}$ dynamics and non-exchangeable $\mathrm{K}$ release in lowland soils of Southern Brazil.

Surface samples $(0.00-0.20 \mathrm{~m})$ from three lowland soils of Paraná State, Brazil (designated Alf, Ert, and Ept) were collected in areas under native vegetation or ancient reforestation in the Paraná State, Brazil. These soils were selected by presenting a wide variation in the original material (Table 1). Soils were classified according to the Brazilian System of Soil Classification (SANTOS et al., 2018) and compared with Keys to USDA Soil Taxonomy (SOIL SURVEY STAFF, 2014) (Table $1)$.

Table 1. Classification, parent material and sampling site of the three lowland soils used in the experiments.

\begin{tabular}{|c|c|c|c|c|c|}
\hline Soil & Brazilian soil classification $^{\dagger}$ & USDA soil taxonomy $^{\dagger \dagger}$ & Parent material & Municipality & \\
\hline$\overline{\text { Alf }}$ & Plintossolo Háplico & Typic Plinthaqualf & Shale $^{(1)}$ & Ponta Grossa & \\
\hline Ert & Gleissolo Háplico & Typic Endoaquert & Alluvial sediments & $\begin{array}{l}\text { Marechal } \\
\text { Rondon }\end{array}$ & Cândido \\
\hline Ept & Cambissolo Háplico & Typic Fragiudept & Furnas sandstone ${ }^{(2)}$ & Ponta Grossa & \\
\hline
\end{tabular}

The physical and chemical properties of the soils were determined by adopting standard procedures (TEIXEIRA et al., 2017), and some characteristics are shown in Table 2. Soil $\mathrm{pH}$ in water was measured potentiometrically in a 1:2.5 (soil:water) suspension using a combined calomel reference glass electrode. Organic matter was quantified by oxidation with potassium dichromate in the presence of sulfuric acid, followed by titration with ammonium $\mathrm{Fe}(\mathrm{II})$ sulfate. $\mathrm{P}$ and $\mathrm{K}$ were extracted by the Mehlich-1 solution ( $\mathrm{HCl} 0.05 \mathrm{~mol}$ $\mathrm{L}^{-1}+\mathrm{H}_{2} \mathrm{SO}_{4} 0.0125 \mathrm{~mol} \mathrm{~L}^{-1}$ ) in a soil:solution ratio of $1: 10$, with $5 \mathrm{~min}$ of stirring time in a horizontal shaker at 120 oscillations per minute and settling for $16 \mathrm{~h}$. $\mathrm{Ca}$ and $\mathrm{Mg}$ were extracted by $1 \mathrm{~mol} \mathrm{~L}^{-1} \mathrm{KCl}$ solution in a soil:solution ratio of $1: 10$, with shaken for $15 \mathrm{~min}$ on a reciprocating shaker at 120 oscillations per minute and standing overnight (16 h) and determined by atomic absorption spectrophotometry. Exchangeable Al was extracted 
by $1 \mathrm{~mol} \mathrm{~L}^{-1} \mathrm{KCl}$ solution and determined by titration with $0.025 \mathrm{~mol} \mathrm{~L}^{-1}$ ammonium hydroxide. Cationic exchange capacity (CEC) was estimated by the summation method $(\mathrm{CEC}=\mathrm{Ca}+\mathrm{Mg}+\mathrm{K}+\mathrm{H}+$ $\mathrm{Al})$. The particle size analysis was performed by the pipette method, based on the decantation speed of different soil particles after dispersion in $0.015 \mathrm{~mol}$ $\mathrm{L}^{-1}\left(\mathrm{NaPO}_{3}\right)_{6} \cdot \mathrm{NaO} / 1 \mathrm{~mol} \mathrm{~L}{ }^{-1} \mathrm{NaOH}$ by overnight shaking. The bulk density measured by the graduated cylinder method. The $\mathrm{Fe}$ and $\mathrm{Al}$ contents, associated with the secondary minerals, were extracted using a 9 mol L ${ }^{-1} \mathrm{H}_{2} \mathrm{SO}_{4}$ solution (1:20 soil:solution ratio), and $\mathrm{Si}$ was removed with $\mathrm{NaOH}$ from the residue of the acid attack. Contents of $\mathrm{Fe}$ and Al were determined using flame atomic absorption spectrophotometry and Si was quantified by gravimetry and expressed in the form of oxides to calculate the weathering index by the molar ratio $\mathrm{Ki}=\left(\% \mathrm{SiO}_{2} / 60\right) /\left(\% \mathrm{Al}_{2} \mathrm{O}_{3} / 102\right)$.

Table 2. Some physicochemical properties of the three lowland soils used in the experiments.

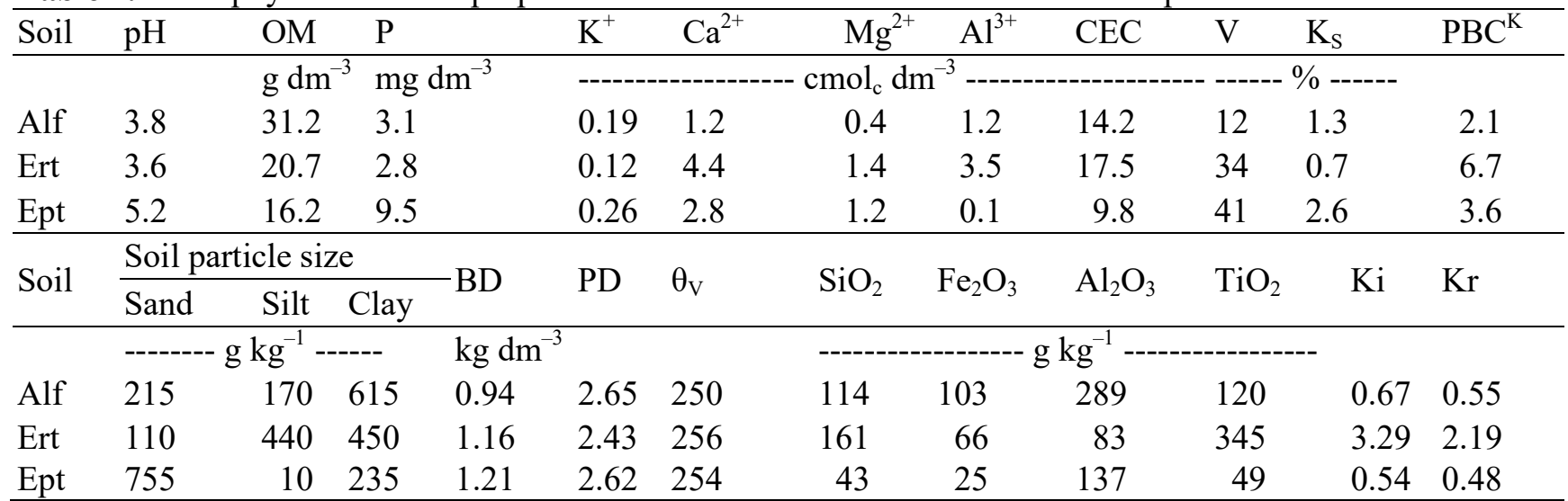

OM: Organic matter. CEC: cationic exchange capacity. V: soil base saturation. $\mathrm{K}_{\mathrm{S}}$ : K saturation of the soil. PBC ${ }^{\mathrm{K}}$ : potential buffering capacity of $\mathrm{K}$ [in $\left.\left(\mathrm{mmol}_{\mathrm{c}} \mathrm{kg}^{-1}\right) /\left(\mathrm{mmol} \mathrm{L}^{-1}\right)^{1 / 2}\right]$. BD: bulk density. PD: Particle density. $\theta_{\mathrm{V}}$ : soil volumetric moisture content at field capacity. Ki: weathering index. Kr: molar ratio $\mathrm{SiO}_{2} / \mathrm{Al}_{2} \mathrm{O}_{3}+\mathrm{Fe}_{2} \mathrm{O}_{3}$.

Limestone $[\mathrm{CaO}=25 \%, \mathrm{MgO}=12 \%$, and CCE (calcium carbonate equivalent) $=96 \%$ ] was applied before of the experiments to raise soil base saturation up to $70 \%$. The soils were then moistened to reach $70 \%$ water retention capacity and incubated for 25 days. Afterward, $7.5 \mathrm{dm}^{3}$ subsamples of each soil were transferred to 8 -L plastic pots with sealed bottoms.

In greenhouse conditions, the soils were subjected to six successive croppings of plants: $\left(1^{\text {st }}\right)$ soybean, $\left(2^{\text {nd }}\right)$ pearl millet $\left(3^{\text {rd }}\right)$ wheat, $\left(4^{\text {th }}\right)$ common beans, $\left(5^{\text {th }}\right)$ soybean, and $\left(6^{\text {th }}\right)$ maize and two $\mathrm{K}$ fertilization levels [no fertilized or fertilized with potash fertilizer]. The treatments consisted of three soils and the addition $(+\mathrm{K})$ or not $(-\mathrm{K})$ of potassium fertilizer, arranged in a randomized block design in a $3 \times 2$ factorial scheme with four replications. Potassium fertilization was performed with potassium chloride $\left(\mathrm{KCl}=60 \%\right.$ of $\left.\mathrm{K}_{2} \mathrm{O}\right)$ in amounts equivalent to raise the soil $\mathrm{K}$ saturation to $6 \%$.

Before sowing of crops, the soils were fertilized with $80 \mathrm{mg} \mathrm{kg}^{-1}$ of nitrogen $(\mathrm{N})$ as ammonium nitrate, $120 \mathrm{mg} \mathrm{kg}^{-1}$ of phosphorus (P) as simple superphosphate, $5 \mathrm{mg} \mathrm{kg}^{-1}$ of sulfur (S) as calcium sulfate, $5 \mathrm{mg} \mathrm{kg}^{-1}$ of copper $(\mathrm{Cu})$ as copper sulfate, $5 \mathrm{mg} \mathrm{kg}^{-1}$ of zinc ( $\mathrm{Zn}$ ) as zinc sulfate, $1 \mathrm{mg}$ $\mathrm{kg}^{-1}$ of molybdenum (Mo) as ammonium molybdate and $2 \mathrm{mg} \mathrm{kg}^{-1}$ of boron (B) as boric acid. At 15 and 30 days after plant emergence was also applied 40 $\mathrm{mg} \mathrm{kg}^{-1}$ of $\mathrm{N}$ as urea solution. Soils were maintained at a water potential near field capacity throughout the experiment by adding deionized water.

All the crops were grown for 45 days, and then the shoot of plants was harvested, oven-dried at $65{ }^{\circ} \mathrm{C}$ for four days, weighed, ground, and subjected to determination of $\mathrm{K}$ concentration as previously described by Malavolta, Vitti and Oliveira (1997). The amount of $\mathrm{K}$ taken up by the plants at each harvest $\left(\mathrm{mg} \mathrm{pot}^{-1}\right)$ was calculated considering the nutrient concentration $\left(\mathrm{g} \mathrm{kg}^{-1}\right)$ and dry matter production $\left(\mathrm{g} \mathrm{pot}^{-1}\right)$.

At the end of the $6^{\text {th }}$ cropping, the soil from each pot was sampled, air-dried, ground to pass through a $2.0 \mathrm{~mm}$ mesh screen. Soil total $\mathrm{K}$ was determined via wet digestion with concentrated acid [hydrofluoric acid ( $\mathrm{HF})$, perchloric acid $\left(\mathrm{HClO}_{4}\right)$ and nitric acid $\left(\mathrm{HNO}_{3}\right)$ ] as described by Teixeira et al. (2017). Exchangeable $\mathrm{K}$ was extracted by the 1.0 mol L ${ }^{-1}$ ammonium acetate solution $\left(\mathrm{CH}_{3} \mathrm{COONH}_{4}\right)$ buffered to $\mathrm{pH} \quad 7.0$ (SANZONOWICZ; MIELNICZUK, 1985). Non-exchangeable $K$ was obtained by the difference between the amount of $\mathrm{K}$ extracted with boiling $1.0 \mathrm{~mol} \mathrm{~L}^{-1} \mathrm{HNO}_{3}$ and $\mathrm{K}$ 
Potassium supplying...

extracted with ammonium acetate solution (KNUDSEN; PETERSON; PRATT, 1982). Solution $\mathrm{K}$ was obtained after equilibration with $1.0 \mathrm{mmol} \mathrm{L}^{-}$ ${ }^{1} \mathrm{SrCl}_{2}$ solution in a soil: solution ratio of $1: 10$ for 30 minutes as described by Mielniczuk (1978). In all extracts, $\mathrm{K}$ concentration was measured by a flame photometer. The amount of soil $\mathrm{K}$, in $\mathrm{mg}$ pot $^{-}$ 1, was calculated considering their concentration, soil volume in each pot $(7.5 \mathrm{~L})$ and soil bulk density of the soils (Table 2).

To calculate the contribution of nonexchangeable $\mathrm{K}$ to plant nutrition was considered the (i) amounts of nutrient outputs (extracted by plants) and inputs (fertilizer) from the soil during the six plant croppings, and the (ii) change in the amount of exchangeable $\mathrm{K}$ in the soils before and after the six successive croppings. Equation 1 proposed by Steiner and Lana (2018) was used to estimate the contribution of non-exchangeable $\mathrm{K}$ to plants:

$\begin{aligned} \Delta K_{\text {Non-ex }} & =K_{\text {Total taken up }}-K_{\text {Fertilizer }}-\left(K_{\text {Soil initial }}\right. \\ \left.-K_{\text {Soil final }}\right) & {[1] }\end{aligned}$

where $\Delta K_{\text {Non-ex }}$ is the amount of $\mathrm{K}$ taken up by plants from soil non-exchangeable pools during the six-successive cropping; $K_{\text {Total taken up is the }}$ amount of $\mathrm{K}$ taken up by crops in the six successive
STEINER et al.

croppings; $K_{\text {Fertilizer }}$ is the amount of $\mathrm{K}$ applied as fertilizer in the six successive croppings; $K_{\text {Soil initial }}$ is the amount of exchangeable $\mathrm{K}$ in the soils before the successive cropping; and, $K_{\text {Soil final }}$ is the amount of exchangeable $\mathrm{K}$ in the soils at the end of the sixth cropping.

Data were subjected to analysis of variance (F-test, $p=0.05$ ), and the effects of soil type and the addition of $\mathrm{K}$ fertilizer were compared by Tukey test and $F$ test, respectively, both at the 0.05 level of confidence, considering a factorial arrangement, with four replications. All analyses were performed using Sisvar 5.6 software for Windows (Statistical Analysis Software, UFLA, Lavras, MG, BRA) (FERREIRA, 2014).

\section{RESULTS AND DISCUSSION}

The results of the analysis of variance showed significant effects $(p<0.05)$ for the main effects of $\mathrm{K}$ fertilizer addition and soil types, as well as for interaction on all the traits measured (Table $3)$. The significant interaction between the main effects of $\mathrm{K}$ addition and soil types indicates that the crop response and soil $\mathrm{K}$ dynamics have different behavior in lowland soils of Paraná State, Brazil.

Table 3. Summary of the analysis of variance for the shoot dry matter (SDM), K uptake, structural K, nonexchangeable $\mathrm{K}\left({ }_{\mathrm{NE}} \mathrm{K}\right)$, exchangeable $\mathrm{K}\left({ }_{\mathrm{E}} \mathrm{K}\right)$, solution $\mathrm{K}$, and non-exchangeable $\mathrm{K}$ contribution $\left({ }_{\mathrm{NE}} \mathrm{KC}\right)$ for the effects of potassium addition and soil types

\begin{tabular}{|c|c|c|c|c|c|c|c|}
\hline \multicolumn{8}{|c|}{ Causes $\quad$ of Probability $>\mathrm{F}$} \\
\hline variation & $\overline{\mathrm{SDM}}$ & K uptake & structural K & ${ }_{\mathrm{NE}} \mathrm{K}$ & ${ }_{\mathrm{E}} \mathrm{K}$ & solution $\mathrm{K}$ & ${ }_{\mathrm{NE}} \mathrm{KC}$ \\
\hline Bloks & 0.893 & 0.457 & 0.534 & 0.587 & 0.341 & 0.217 & 0.547 \\
\hline $\mathrm{K}$ addition $(\mathrm{K})$ & $<0.000$ & $<0.000$ & $<0.000$ & $<0.000$ & $<0.000$ & $<0.000$ & $<0.000$ \\
\hline Soil (S) & $<0.000$ & $<0.000$ & $<0.000$ & $<0.000$ & $<0.000$ & $<0.000$ & $<0.000$ \\
\hline $\mathrm{K} \times \mathrm{S}$ & $<0.000$ & 0.038 & $<0.000$ & $<0.000$ & $<0.000$ & 0.003 & $<0.000$ \\
\hline CV (\%) & 6.52 & 9.17 & 11.37 & 12.71 & 11.32 & 15.27 & 6.11 \\
\hline
\end{tabular}

\section{Dry matter yield and $K$ uptake}

The K supply potential to the plants was different between soils (Figure 1), due to the wide range of parent material and exchangeable $\mathrm{K}$ concentration of soils (Table 2). The relative dry matter yield in the first cropping of treatment no fertilized with $\mathrm{K}$ ranged from 78 to $97 \%$ (Figure 1). The high dry matter yield of soybean $\left(1^{\text {st }}\right.$ cropping $)$, especially for the Alf and Ept, was due to the high levels of readily available $\mathrm{K}$ (available $\mathrm{K} \geq 0.15$ $\mathrm{cmol}_{\mathrm{c}} \mathrm{dm}^{-3}$ ) (Table 2). In the second cropping, the relative dry matter yield ranged from 23 to $76 \%$ (Figure 1). From the third cropping, the relative dry matter yield was less than $44 \%$. These data indicate that the initial exchangeable $\mathrm{K}$ concentration was able to meet the demand of plants only the first cropping. The lower shoot dry matter yield of plants, from the second crop without K supply can be attributed to the depletion of readily available $\mathrm{K}$ pools with the course of successive cropping.

The shoot dry matter yield accumulated during six successive croppings was affected by the addition of $\mathrm{K}$ and soil type (Figure 2A). In general, the highest yield of shoot dry matter was obtained in the Ert and Ept, regardless of the addition or not of $\mathrm{K}$ fertilizer. These results are due to the high $\mathrm{PBC}^{\mathrm{K}}$ of these soils (Table 2). A soil with a large $\mathrm{PBC}^{\mathrm{K}}$ will have a greater capacity to maintain the activity of $\mathrm{K}$ in the soil solution. This indicated that soils of high $\mathrm{PBC}^{\mathrm{K}}$ have enough $\mathrm{K}$ in reserve to replenish used $\mathrm{K}$ by crops while those of low $\mathrm{PBC}^{\mathrm{K}}$ will only replace used $\mathrm{K}$ slowly. Thus, the release of $\mathrm{K}$ will be rapid and slow accordingly. It then implies that soils with high $\mathrm{PBC}^{\mathrm{K}}$ will be able to maintain 
solution $\mathrm{K}$ intensity against plant depletion for longer periods while those of low values will have low capacity to maintain the activity of $\mathrm{K}$ in the solution and hence frequent fertilization.

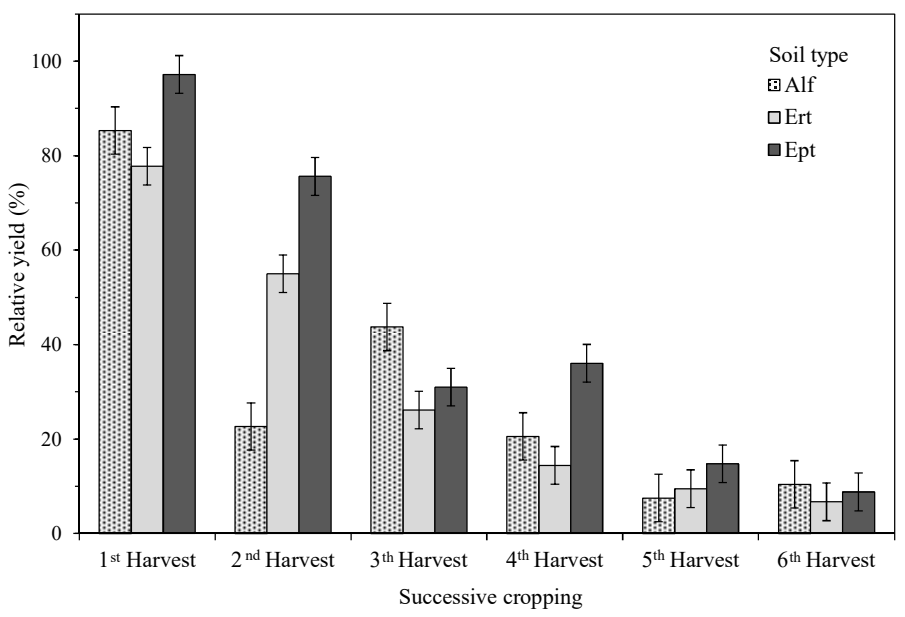

Figure 1. Relative shoot dry matter yield of treatments non-fertilized with $\mathrm{K}$ during the six-successive croppings in the three lowland soils of Paraná State, Brazil. Vertical lines represent the mean standard error. Alf: Typic Plinthaqualf; Ert: Typic Endoaquert; Ept: Typic Fragiudept.

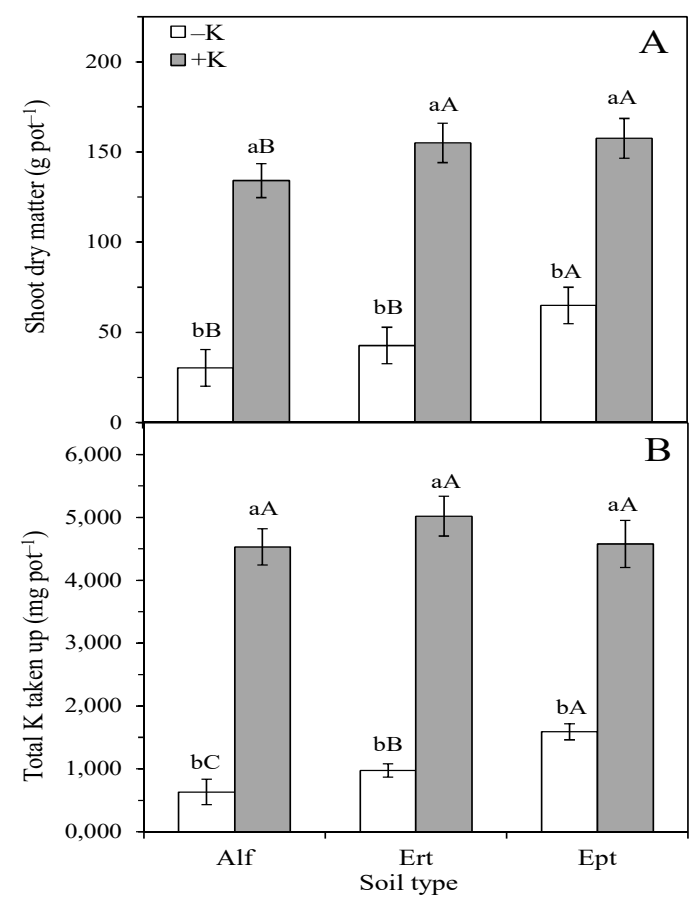

Figure 2. Total shoot dry matter yield - (A) and total K taken up - (B) during the six successive croppings in the three lowland soils of Paraná State, Brazil fertilized $(+\mathrm{K})$ and no-fertilized $(-\mathrm{K})$ with $\mathrm{K}$ fertilizer. Vertical lines represent the mean standard error. Bars represented by the same uppercase letters, between the different Paraná soils and the same lowercase letters, for the addition of $\mathrm{K}$ fertilizer, are not different by Tukey test and $\mathrm{F}$ test, respectively, both at the 0.05 level of confidence. Alf: Typic Plinthaqualf; Ert: Typic Endoaquert; Ept: Typic Fragiudept.

The yield of shoot dry matter accumulated in the six croppings ranged from 134 to $158 \mathrm{~g} \mathrm{pot}^{-1}$ (149 $\mathrm{g} \mathrm{pot}^{-1}$, on average) and from 30 to $65 \mathrm{~g} \mathrm{pot}^{-1}$ (46 $\mathrm{g} \mathrm{pot}^{-1}$, on average), respectively, with the addition or not of potassium fertilizer (Figure 2A). These data indicated that the dry matter yield with the addition of $\mathrm{K}$ was $224 \%$ higher when compared to treatment no fertilized with $\mathrm{K}$. This demonstrates the importance of $\mathrm{K}$ fertilization in tropical lowland soils, once the $\mathrm{K}$ reserves of these soils, in general, are not sufficient to meet the demand of plants and achieve high crop yields.

When the soils were fertilized with $\mathrm{K}$, the $\mathrm{K}$ concentration in the shoot dry matter of plants in all 
Potassium supplying...

cropping remained in the range considered adequate for optimal growth and development of plants (from 19 to $36 \mathrm{~g} \mathrm{~kg}^{-1}$ of K). According to Malavolta, Vitti and Oliveira (1997), the range of $\mathrm{K}$ concentrations considered suitable for soybean is $17-25 \mathrm{~g} \mathrm{~kg}^{-1}$, pearl millet from $15-35 \mathrm{~g} \mathrm{~kg}^{-1}$, wheat $15-30 \mathrm{~g} \mathrm{~kg}^{-1}$, common beans $20-25 \mathrm{~g} \mathrm{~kg}^{-1}$ and maize $17-35 \mathrm{~g} \mathrm{~kg}^{-}$ ${ }^{1}$. However, in the treatments not fertilized with $\mathrm{K}$, the $\mathrm{K}$ concentration in the shoot dry matter of plants decreases after the second cropping $\left(<20 \mathrm{~g} \mathrm{~kg}^{-1}\right.$ of $\mathrm{K})$, indicating that there was depletion of readily available K pools of soils, as can be seen in Figure

\section{STEINER et al.}

3. After the third cropping, the $\mathrm{K}$ concentration in the shoot dry matter was below the optimum range for plant growth in all soils. Potassium concentration after the third cropping ranged from 18.2 to $19.8 \mathrm{~g} \mathrm{~kg}^{-1}$ at the common bean, from 5.6 to $6.3 \mathrm{~g} \mathrm{~kg}^{-1}$ at the soybean, and 7.7 to $15.2 \mathrm{~g} \mathrm{~kg}^{-1}$ at the maize. Symptoms of severe K deficiencies were observed in the last three crops (i.e., common bean, soybean, and maize). Potassium deficiency symptoms appeared initially on older leaves as chlorotic spots but soon developed for dark necrotic lesions (dead tissue).

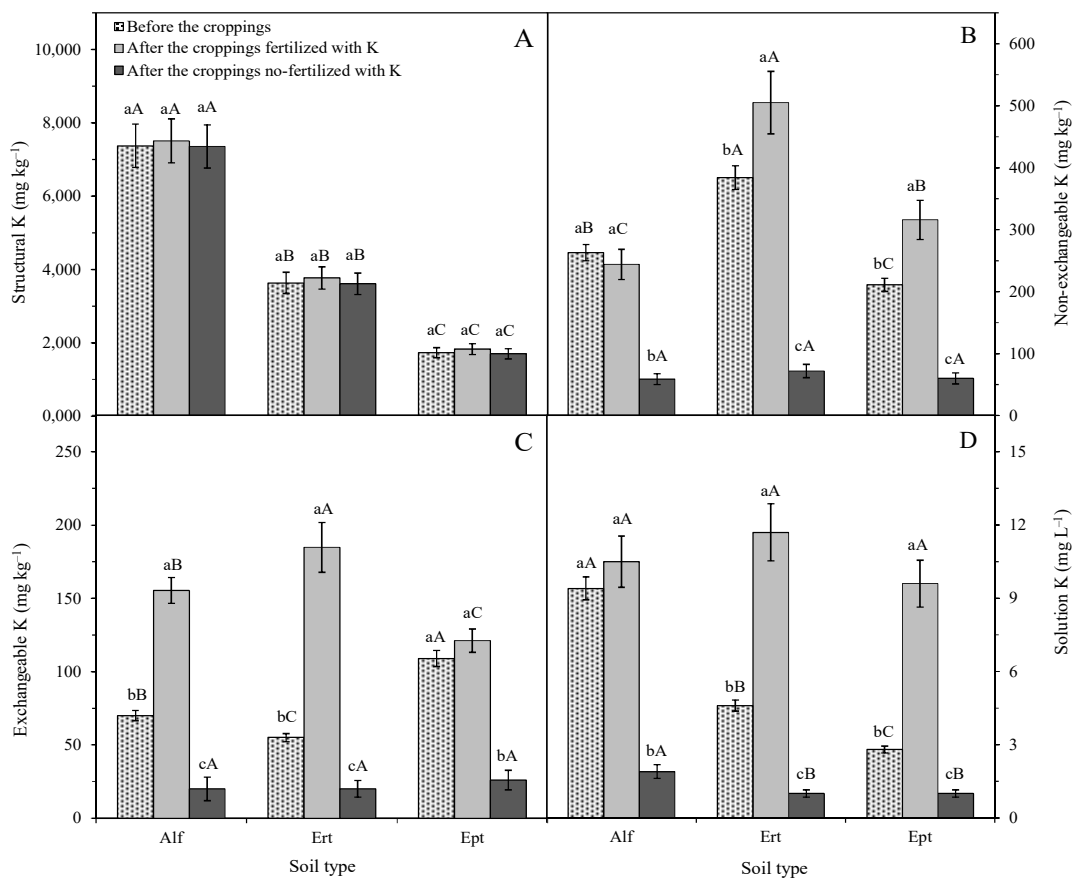

Figure 3. Concentrations of structural $\mathrm{K}$, non-exchangeable $\mathrm{K}$, exchangeable $\mathrm{K}$ and solution $\mathrm{K}$ in the three lowland soils of Paraná State, Brazil, before and after the sixth successive cropping of plants fertilized $(+\mathrm{K})$ and no-fertilized $(-\mathrm{K})$ with $\mathrm{K}$ fertilizer. Vertical lines represent the mean standard error. Bars represented by the same uppercase letters, between the different lowland soils and the same lowercase letters, for the addition of K fertilizer, are not different by the Tukey test at the 0.05 level of confidence. Alf: Typic Plinthaqualf; Ert: Typic Endoaquert; Ept: Typic Fragiudept.

The total amount of $\mathrm{K}$ taken up by the plants during the six successive croppings was affected by $\mathrm{K}$ fertilizer application and soil type (Figure 2B). As expected, the $\mathrm{K}$ application significantly increased $\mathrm{K}$ amount taken up during the six successive croppings in all soils. The total amount of $\mathrm{K}$ taken up by the plants with the addition of $\mathrm{K}\left(4,710 \mathrm{mg} \mathrm{pot}^{-1}\right.$, on average) was $342 \%$ higher when compared to treatment no fertilized with $\mathrm{K}$ $\left(1,065 \mathrm{mg} \mathrm{pot}^{-1}\right.$, on average). When the soils were not fertilized with $\mathrm{K}$, the higher $\mathrm{K}$ amount taken up by the plants was obtained in the Ept (Figure 2B). These results are due to the high levels of readily available $\mathrm{K}$ of this soil (Table 1). On the other hand, the lower $\mathrm{K}$ amount taken up by the plants obtained in the Alf was due to lower availability and lower $\mathrm{PBC}^{\mathrm{K}}$ of this soil (Table 1).

\section{Soil potassium pools}

Potassium supply capacity to plants in the short and medium-term had a wide variation between soils (Figure 3). Potassium supply potential of soils is conceived to include $\mathrm{K}$ supplied from solution $\mathrm{K}$, exchangeable $\mathrm{K}$, and non-exchangeable $\mathrm{K}$ pools. The order of abundance of the $\mathrm{K}$ pools in the soils is structural $\mathrm{K}>$ non-exchangeable $\mathrm{K}>$ exchangeable $\mathrm{K}>$ solution $\mathrm{K}$ (Figure 3 ). The soil structural $\mathrm{K}$ constituted 84 to $96 \%$ of the total $\mathrm{K}$ and ranged from 1,730 to $7,373 \mathrm{mg} \mathrm{kg}^{-1}$ (Figure 3A). 
The $\mathrm{K}$ content of soil minerals varies with the source of parent material and the degree of weathering (STEINER; LANA, 2018). Higher structural $\mathrm{K}$ concentration was observed in the Typic Plinthaqualf (Alf) derived from the Ponta Grossa Formation sediments composed of very micaceous shale's (Table 1). The pellitic sedimentary rocks (shales) can contain up to 30,000 $\mathrm{mg} \mathrm{kg} \mathrm{kf}^{-1}$ o (SPARKS; HUANG, 1985). These results are associated with the presence of mica as a natural source of $\mathrm{K}$ in its structure. The mineral $\mathrm{K}$ reserves of soil are found in primary minerals such as mica and feldspar, and secondary minerals such as illite, vermiculite and interstratified clay minerals (SPARKS; HUANG, 1985). Silva et al. (2000) also found the highest values of total $\mathrm{K}$ in soils derived from pellitic rocks, which according to Melo et al. (2005) are materials relatively rich in $\mathrm{K}$ mineral.

Soil structural $\mathrm{K}$ concentration was not affected by successive cropping and the addition of $\mathrm{K}$ fertilizer (Figure 3A). This indicates that the structural K was not easily released to the plants during the six croppings of plants, confirming the results reported by Steiner and Lana (2018) in upland soils of southern Brazil.

Non-exchangeable $\mathrm{K}$ concentration in the soils was affected by the $\mathrm{K}$ fertilizer application (Figure 3B). Potassium addition significantly increased non-exchangeable $\mathrm{K}$ concentration in the soils, except for the Alf (Figure 3B). Initial nonexchangeable $\mathrm{K}$ concentrations ranged from 211 to $384 \mathrm{mg} \mathrm{kg}^{-1}$ (286 $\mathrm{mg} \mathrm{kg}^{-1}$, on average), and after the sixth cropping, these concentrations increased from 244 to $505 \mathrm{mg} \mathrm{kg}^{-1}$ (355 $\mathrm{mg} \mathrm{kg}^{-1}$, on average), indicating a mean increase of $24 \%$. This increase in the non-exchangeable $\mathrm{K}$ concentration may be because the frequent application of $\mathrm{K}$ fertilizers results in changes in soil $K$ minerals (BORTOLUZZI et al., 2005). In a clay soil of the Jaboticabal, São Paulo, Chiba et al. (2008) found that the application of $900 \mathrm{~kg} \mathrm{ha}^{-1} \mathrm{yr}^{-1}$ of $\mathrm{K}_{2} \mathrm{O}$ increased the non-exchangeable $\mathrm{K}$ concentration of $40 \%$. In a study conducted for 11 years in an Arenic Hapludult of Santa Maria (RS), Bortoluzzi et al. (2005) found increased of non-exchangeable $\mathrm{K}$ with the addition of $\mathrm{K}$, reflecting in the increased of micaceous minerals (i.e., illite and illite-smectite interstratified clay), compared to the soil without $\mathrm{K}$ fertilization. According to Steiner and Lana (2018), the change of soil $\mathrm{K}$ minerals due to the weathering process can be minimized with the addition of $\mathrm{K}$ fertilizers.

When the soils were not fertilized with K ($\mathrm{K}$ ), the non-exchangeable $\mathrm{K}$ concentration decreases in all the soils (Figure 3B), indicating that these non-exchangeable sources contributed to the supply of $\mathrm{K}$ to plants. Initial non-exchangeable $\mathrm{K}$ concentrations ranged from 211 to $384 \mathrm{mg} \mathrm{kg}^{-1}$ (286 $\mathrm{mg} \mathrm{kg}{ }^{-1}$, on average), and at the end of the sixth cropping, these concentrations decreased from 59 to $72 \mathrm{mg} \mathrm{kg}^{-1}$ (64 $\mathrm{mg} \mathrm{kg}^{-1}$, on average), representing a decrease from the initial mean of $78 \%$. The depletion of soil non-exchangeable $\mathrm{K}$ pools with successive cropping, confirms the results reported by Steiner and Lana (2018) in upland soils of Southern Brazil, who found that the nonexchangeable $\mathrm{K}$ at the end of the $6^{\text {th }}$ cropping was reduced in up to $68 \%$ in the treatment without $\mathrm{K}$ fertilizer.

Fraga et al. (2009) reported that the K supply in the short term ( $1^{\text {st }}$ cropping) was conditioned by the soil exchangeable $\mathrm{K}$ concentration, while in the course of successive cropping ( $2^{\text {nd }}$ and $3^{\text {rd }}$ cropping) this supply was obtained by the release of $\mathrm{K}$ from non-exchangeable sources. Indeed, when solution $\mathrm{K}$ and exchangeable $\mathrm{K}$ are reduced to low levels by plant uptake, nonexchangeable $K$ can be released from clay interlayers (BORTOLUZZI et al., 2005). Nonexchangeable $\mathrm{K}$ can be a source available to plants in the medium term. However, the release rate of $\mathrm{K}$ from the non-exchangeable pool is influenced by particle size and chemical and mineralogical composition of the soil (MELO et al., 2005).

The intense cropping and/or $\mathrm{K}$ fertilizer application may affect the soil $\mathrm{K}$ dynamic, leading to changes in clay mineral composition (VELDE; PECK 2002; BORTOLUZZI et al., 2005; ROSOLEM; VICENTINI; STEINER, 2012). Hinsinger and Jaillard (1993) observed the formation of vermiculite, in detriment of illite, in the rhizosphere soil of ryegrass plants in only 32 days of growing. Under these conditions, the release of $\mathrm{K}$ from the illite layers, induced by the action of plant roots, was almost complete. Rosolem, Vicentini and Steiner (2012) showed that the K depletion in soil under intense cropping could occur in both exchangeable and non-exchangeable pools, even when frequent additions of $\mathrm{K}$ fertilizers are performed.

Soil exchangeable $\mathrm{K}$ concentration was affected by successive cropping and $\mathrm{K}$ fertilizer application (Figure 3C). The $\mathrm{K}$ application significantly increased exchangeable $\mathrm{K}$ concentration in the soils, except for the Alf (Figure 3C). These increases, however, were dependents of soil type and initial exchangeable $\mathrm{K}$ concentration. Initial exchangeable $\mathrm{K}$ concentrations ranged from 55 to $109 \mathrm{mg} \mathrm{kg}^{-1}$ (78 $\mathrm{mg} \mathrm{kg}^{-1}$, on average), and at the end of the sixth cropping, these concentrations 
increased from 121 to $185 \mathrm{mg} \mathrm{kg}^{-1}\left(154 \mathrm{mg} \mathrm{kg}^{-1}\right.$, on average), indicating a mean increase of $97 \%$. The increase in the exchangeable $\mathrm{K}$ concentration of soils was due to the fact the $\mathrm{K}$ fertilization promotes greater retention of $\mathrm{K}$ in the soil exchange complex (ROSOLEM; VICENTINI; STEINER, 2012; STEINER; LANA, 2018). However, these exchangeable $\mathrm{K}$ levels are determined by the ability of exchange sites in adsorbing $\mathrm{K}$ ion, where its increase is only possible by the increase in the number of such sites.

When the soils were not fertilized with K ($\mathrm{K})$, the exchangeable $\mathrm{K}$ concentration decreases (Figure 3C). Before the cropping, the exchangeable $\mathrm{K}$ concentrations ranged from 55 to $109 \mathrm{mg} \mathrm{kg}^{-1}$ (78 $\mathrm{mg} \mathrm{kg}$, on average), and at the end of the sixth cropping, these values decreased from 20 to $26 \mathrm{mg}$ $\mathrm{kg}^{-1}$ (22 $\mathrm{mg} \mathrm{kg}^{-1}$, on average), representing a decrease from the initial mean of $72 \%$ (Figure 3C). Bortoluzzi et al. (2005) reported similar results in an experiment conducted for 11 years in an Arenic Hapludult of the State of Rio Grande do Sul, Brazil. These authors verified that when the soil was not fertilized with $\mathrm{K}$, the soil available $\mathrm{K}$ reduced from $50 \mathrm{mg} \mathrm{kg}^{-1}$ at the beginning of the experiment to 38 $\mathrm{mg} \mathrm{kg}{ }^{-1}$ in the first year, and $30 \mathrm{mg} \mathrm{kg}^{-1}$ at the end of the second year. On the other hand, when the soil was fertilized with $\mathrm{K}$, the soil available $\mathrm{K}$ concentrations increased from $50 \mathrm{mg} \mathrm{kg}^{-1}$ to 80 and $85 \mathrm{mg} \mathrm{kg}^{-1}$, at the end of the first and second year, respectively. After this period, the available $\mathrm{K}$ levels in both treatments remained constant around 30 and
$90 \mathrm{mg} \mathrm{kg}{ }^{-1}$, respectively, with and without $\mathrm{K}$ fertilization. According to these authors, the maintenance of these levels for nearly a decade with intense cropping of K-demanding crops was only ensured by the release of $\mathrm{K}$ from weathering of $\mathrm{K}$ feldspars and phyllosilicates.

In general, in this study, the exchangeable $\mathrm{K}$ concentration of 22 and $150 \mathrm{mg} \mathrm{kg}^{-1}$ may be considered the lower and upper limits for the soil $\mathrm{K}$ balance in case of exhaustion and excess of $\mathrm{K}$, respectively. According to Velde and Peck (2002), these limits are determined mainly by the mineralogy of soils. The results presented here for the exchangeable $\mathrm{K}$ and non-exchangeable $\mathrm{K}$ in the soils (Figure 4) confirmed the results reported by Fraga et al. (2009), Vieira et al. (2016) and Rosolem, Vicentini and Steiner (2012). These authors showed that the non-exchangeable $\mathrm{K}$ pool could maintain or even enhance soil exchangeable $\mathrm{K}$ reserves in the long term. However, maintaining such a situation in the long term may decrease soil $\mathrm{K}$ reserves, compromising the movement of the nutrient into the soil solution and thus also the successful establishment and growth of crops. In long-term experiments, Borkert et al. (1997) also observed a decrease in exchangeable $\mathrm{K}$ concentration in different soil types during successive years of the soybean crop and found that it would be necessary to apply at least $80 \mathrm{~kg} \mathrm{ha}^{-1} \mathrm{yr}^{-}$ ${ }^{1}$ of $\mathrm{K}_{2} \mathrm{O}$ to maintain soil exchangeable $\mathrm{K}$ concentrations and avoid depletion of the soil $\mathrm{K}$ reserves.

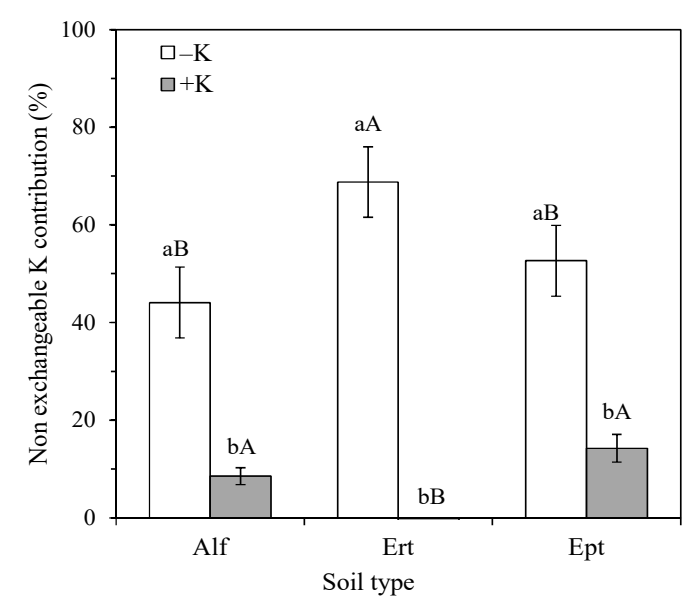

Figure 4. Non-exchangeable $\mathrm{K}$ contribution to $\mathrm{K}$ uptake of plants during the six successive croppings in the three lowland soils of Paraná State, Brazil, fertilized $(+\mathrm{K})$ and no-fertilized $(-\mathrm{K})$ with $\mathrm{K}$ fertilizer. Vertical lines represent the mean standard error. Bars represented by the same uppercase letters, between the different lowland soils and the same lowercase letters, for the addition of $\mathrm{K}$ fertilizer, are not different by Tukey test and $\mathrm{F}$ test, respectively, both at the 0.05 level of confidence. Alf: Typic Plinthaqualf; Ert: Typic Endoaquert; Ept: Typic Fragiudept. 
Soil solution K concentration was affected by successive cropping and $\mathrm{K}$ fertilizer application (Figure 3D). The addition of $\mathrm{K}$ fertilizer resulted in significant increases in solution $\mathrm{K}$ concentration in the soils, except for the Alf. These increases, however, were dependents of soil type and initial exchangeable $\mathrm{K}$ concentration. Initial solution $\mathrm{K}$ concentration ranged from 2.8 to $9.4 \mathrm{mg} \mathrm{L}^{-1}(5.6 \mathrm{mg}$ $\mathrm{L}^{-1}$, on average), and at the end of the sixth cropping, these concentrations increased from 9.6 to $11.6 \mathrm{mg} \mathrm{L}^{-1}$ (10.6 $\mathrm{mg} \mathrm{L}^{-1}$, on average), indicating a mean increase of $89 \%$. In turn, when the soils were not fertilized with $\mathrm{K}(-\mathrm{K})$, the initial solution $\mathrm{K}$ concentration ranged from 2.8 to $9.4 \mathrm{mg} \mathrm{L}^{-1}(5.6 \mathrm{mg}$ $\mathrm{L}^{-1}$, on average), and at the end of the sixth cropping these values decreased from 1.0 to $1.9 \mathrm{mg} \mathrm{L}^{-1}(1.2$ $\mathrm{mg} \mathrm{L}^{-1}$, on average), representing a decrease from the initial mean of $78 \%$. These results indicate that has reached a balance between pools of solution $\mathrm{K}$ and exchangeable $\mathrm{K}$ with a minimum of soluble $\mathrm{K}$ in the soil-plant system.

\section{Non-exchangeable $K$ contribution}

The $\mathrm{K}$ addition and soil type affected the non-exchangeable $\mathrm{K}$ contribution to $\mathrm{K}$ uptake of plants during the six cropping's (Figure 4). When the soils were not fertilized with $\mathrm{K}(-\mathrm{K})$, the nonexchangeable $\mathrm{K}$ contribution to total $\mathrm{K}$ uptake of plants ranged from 44 to $69 \%$. These results report the importance of non-exchangeable $\mathrm{K}$ pools in the supply of this nutrient to plants in agricultural production systems. With $\mathrm{K}$ fertilization $(+\mathrm{K})$, the non-exchangeable $\mathrm{K}$ contribution to total $\mathrm{K}$ uptake of plants ranged was 9 and 14\% for the Alf and Ept. These results show that even with the application of high rates of $\mathrm{K}$ fertilizer the successive cropping also extracted $\mathrm{K}$ of non-exchangeable pools. However, for the Ert there was no non-exchangeable $\mathrm{K}$ contribution to total $\mathrm{K}$ uptake of plants during the cropping (Figure 4).

In a sandy soil of Rio Grande do Sul, Brazil, Simonete et al. (2002) estimated that even considering the residual effect of ryegrass $\mathrm{K}$ fertilization under continuous ryegrass-rice cropping system, at least $30 \%$ of the total $\mathrm{K}$ taken up by plants was from the non-exchangeable $\mathrm{K}$ pool. In lowland soils of Rio Grande do Sul, Brazil,
Fraga et al. (2009) found that non-exchangeable K contribution to the $\mathrm{K}$ nutrition of rice plants ranged 12 to $72 \%$ in the treatments no fertilized and fertilized with $\mathrm{K}$ fertilizer, respectively. The exploitation of $\mathrm{K}$ pools initially considered nonexchangeable for plants has been commonly reported in the literature, even in scenarios involving $\mathrm{K}$ fertilizer application (VIEIRA et al., 2016; STEINER; LANA, 2018). Rosolem, Vicentini, and Steiner (2012) found that the nonexchangeable $\mathrm{K}$ pools were the main sources of the nutrient for successive cropping of ruzigrass [Urochloa ruziziensis (Syn. Brachiaria ruziziensis)]. Rosolem, Machado and Ribeiro (1988) found that when the exchangeable $\mathrm{K}$ concentration is less than $60 \mathrm{mg} \mathrm{kg}^{-1}$ there was the release of $\mathrm{K}$ from nonexchangeable sources, and these sources would be responsible for the $\mathrm{K}$ nutrition of plants, and the maintenance of appropriate levels of soil exchangeable $\mathrm{K}$.

\section{CONCLUSIONS}

The initial exchangeable $\mathrm{K}$ concentration upper at $0.19 \mathrm{cmol}_{\mathrm{c}} \mathrm{dm}^{-3}$ (or $74 \mathrm{mg} \mathrm{dm}^{-3}$ ) in the Typic Plinthaqualf (Alf) and Typic Fragiudept (Ept) was enough to achieve higher soybean yield at $85 \%$ of maximum yield in the first cropping, indicating no need to fertilize with $K$ because of the contribution of non-exchangeable $\mathrm{K}$.

When the soils were not fertilized with $\mathrm{K}$, the successive cropping of plants resulted in a continuous depletion process of non-exchangeable $\mathrm{K}$ and exchangeable $\mathrm{K}$ pools. However, this depletion was less pronounced in soils with a higher potential buffer capacity of $\mathrm{K}$.

The concentrations of non-exchangeable $\mathrm{K}$ and exchangeable $\mathrm{K}$ were increased with the addition of $\mathrm{K}$ fertilizers, indicating the occurrence of $\mathrm{K}$ fixation in lowland soils.

The non-exchangeable $\mathrm{K}$ contribution to $\mathrm{K}$ nutrition of plants during the six-cropping ranged from 44 to $69 \%$ in the treatments without the addition of $\mathrm{K}$ fertilizer, reporting the importance of non-exchangeable $\mathrm{K}$ pools in the supply of this nutrient to plants in agricultural production systems.

RESUMO: Os efeitos dos cultivos sucessivos e da adubação potássica na dinâmica de potássio $(\mathrm{K})$ do solo e na mobilização do K não-trocável para às plantas em três solos de varzea do Estado do Paraná, Brasil, foram investigados neste estudo. Amostras dos três solos de várzea foram submetidas à adição ou não de fertilizante potássico e a seis cultivos sucessivos de plantas (soja, milheto, trigo, feijão, soja e milho). As culturas foram cultivadas em vasos de 8-L por 45 dias e, ao final do sexto cultivo, foram coletadas amostras de solos para a deteminação das diferentes formas de $\mathrm{K}$ do solo. Os solos de vázea diferenciaram-se na capacidade 
de suprir $\mathrm{K}$ às plantas a curto e médio prazo, devido à ampla variação do material de origem e dos teores de $\mathrm{K}$ na solução, $\mathrm{K}$ trocável, $\mathrm{K}$ não-trocável e $\mathrm{K}$ estrutural. Quando os solos não foram adubados com $\mathrm{K}$, o cultivo sucessivo de plantas resultou em um processo contínuo de esgotamento das formas de $\mathrm{K}$ não-trocável e $\mathrm{K}$ trocável, sendo menos acentuada nos solos com maior poder tampão de potássio. Os teores de K não-trocável e $\mathrm{K}$ trocável aumentaram com a adição de fertilizantes potássicos, indicando a ocorrência de fixação de K pelo solo. A contribuição do K não-trocável para a nutrição das plantas durante os seis cultivos variou de 44 a $69 \%$ no tratamento sem adição de fertilizante potássico. Estes resultados reportam a importância das formas de K não-trocável para o suprimento deste nutriente às plantas nos sistemas de produção agrícolas.

PALAVRAS-CHAVE: K trocável. Cultivos intensivos. K não-trocável. Balanço de potássio do solo.

\section{REFERENCES}

BARBER, S. A. Soil Nutrient Bioavailability: A Mechanistic Approach. $2^{\text {nd }}$ Ed., New York: John Wiley, 1995.

BILIAS, F. BARBAYIANNIS, N. Contribution of non-exchangeable potassium on its quantity-intensity relationships under K-depleted soils, Archives of Agronomy and Soil Science, Abingdon, v. 64, n. 14, p. 1988-2004, 2018. https://doi.org/10.1080/03650340.2018.1472376

BORKERT, C. M.; FARIAS, J. R. B.; SFREDO, G. J.; TUTIDA, F.; SPOLADORI, C. L. Resposta da soja à adubação e disponibilidade de potássio em Latossolo Roxo distrófico. Pesquisa Agropecuária Brasileira, Brasília, v. 32, n. 10, p. 1235-1249, p. 1997.

BORTOLUZZI, E. C.; RHEINHEIMER, D. S.; KAMINSKI, J.; GATIBONI, L. C.; TESSIER, D. Alterações na mineralogia de um Argissolo do Rio Grande do Sul submetido à fertilização potássica. Revista Brasileira de Ciência do Solo, Viçosa, v. 29, n.3, p. 327-335, 2005. https://doi.org/10.1590/s0100-06832005000300002

CHIBA, M. K.; NATALE, W.; CRUZ, M. C. P.; TEIXEIRA, L. A. J.; CENTURION, J. F. Potássio nas frações texturais de Latossolo. Acta Scientiarum. Agronomy, Maringá, v. 30, n. 4, p. 581-587, 2008.

https://doi.org/10.4025/actasciagron.v30i4.5321

FERREIRA, D. F. Sisvar: an Guide for its Bootstrap procedures in multiple comparisons. Ciência e Agrotecnologia, Lavras, v. 38, n. 2, p. 109-112, 2014. http://dx.doi.org/10.1590/S1413-70542014000200001

FRAGA, T. I.; GENRO-JUNIOR, S. A.; INDA, A. V.; ANGHINONI, I. Suprimento de potássio e mineralogia de solos de várzea sob cultivos sucessivos de arroz irrigado. Revista Brasileira de Ciência do Solo, Viçosa, v. 33, n. 3, p. 497-506, 2009. https://doi.org/10.1590/s0100-06832009000300003

HINSINGER, P.; JAILLARD, B. Root-induced release of interlayer potassium and vermiculitization of hlogopite as related to potassium depletion in the rhizosphere of ryegrass. Journal of Soil Science, Oxford, v. 44, n. 3, p. 525-534, 1993. https://doi.org/10.1111/j.1365-2389.1993.tb00474.x

KNUDSEN, D.; PETERSON, G. A.; PRATT, P. F. Lithium, sodium, and potassium. In: PAGE, A. L. (Ed.) Methods of soil analysis. $2^{\text {nd }}$ ed. (p. 225-246), Madison: American Society of Agronomy, 1982. p.225-246.

MALAVOLTA, E. A.; VITTI, G. C.; OLIVEIRA, A. S. Avaliação do estado nutricional das plantas: princípios e aplicações. Piracicaba: Potafos, 1997, 319p.

MELO, V. F.; CORRÊA, G. F.; RIBEIRO, N. A.; MASCHIO, P. A. Cinética de liberação de potássio e magnésio pelos minerais da fração areia de solos do Triângulo Mineiro. Revista Brasileira de Ciência do Solo, Viçosa, v. 29, n. 4, p. 533-545, 2005. https://doi.org/10.1590/s0100-06832005000400006 
MIELNICZUK, J. O potássio no solo. Piracicaba: Instituto da Potassa e do Fosfato/Instituto Internacional da Potassa, 1978. 79p. (Boletim Técnico, 2).

ROSOLEM, C. A.; MACHADO, J. R.; RIBEIRO, D. B. O. Formas de potássio no solo e nutrição potássica da soja. Revista Brasileira de Ciência do Solo, Campinas, v. 12, n. 1, p. 121-125, 1988.

ROSOLEM, C. A.; VICENTINI, J. P. T. M. M.; STEINER, F. Suprimento de potássio em função da adubação potássica residual em um Latossolo Vermelho do Cerrado. Revista Brasileira de Ciência do Solo, Viçosa, v. 36, n. 5, p. 1507-1515, 2012. https://doi.org/10.1590/s0100-06832012000500015

SANTOS, H. G.; JACOMINE, P. K. T.; ANJOS, L. H. C.; OLIVEIRA, V. A.; LUMBRERAS, J. F.; COELHO, M. R.; ALMEIDA, J. A.; ARAUJO FILHO, J. C.; OLIVEIRA, J. B.; CUNHA, T. J. F. Sistema Brasileiro de Classificação de Solos. $5^{\text {a }}$ Ed. Brasília, DF: EMBRAPA, 2018. 353p.

SANZONOWICZ, C.; MIELNICZUK, J. Distribuição de K no perfil de um solo influenciado pela planta, fontes e métodos de aplicação de adubos. Revista Brasileira de Ciência do Solo, Campinas, v. 9, n.1, p. 45$50,1985$.

SILVA, I. R.; FURTINI NETO, A. E.; FERNANDEZ, L. A.; CURI, N.; VALE, F. R. Formas, relação quantidade/intensidade e biodisponibilidade de potássio em diferentes Latossolos. Pesquisa Agropecuária Brasileira, Brasília, v. 35, n. 10, p. 2065-2073, 2000. https://doi.org/10.1590/S0100-204X2000001000019

SIMONETE, M. A.; VAHL, L. C.; FABRES, R. T.; COUTO, J. R. R.; LUNARDI, R. Efeito residual da adubação potássica do azevém sobre o arroz subsequente em plantio direto. Revista Brasileira de Ciência do Solo, Viçosa, v. 26, n. 3, p. 721-727, 2002. https://doi.org/10.1590/s0100-06832002000300017

SIMONSSON, M.; HILLIER, S.; ÖBORN, I. Changes in clay minerals and potassium fixation capacity as a result of release and fixation of potassium in long term field experiments. Geoderma, Amsterdam, v. 151, n. 34, p. 109-120, 2009. https://doi.org/10.1016/j.geoderma.2009.03.018

SOIL SURVEY STAFF. Keys to soil taxonomy. $12^{\text {th }}$ ed. Washington(DC): USDA - Natural Resources Conservation Service, 2014.

SPARKS, D. L.; HUANG, P. M. Physical, chemistry of soil potassium. In: MUNSON, R. D. (ed.) Potassium in agriculture. Madison: Soil Science Society of America, 1985. p. 1-48.

STEINER, F.; LANA, M. C.; ZOZ, T.; FRANDOLOSO, J. F. Changes in potassium pools in Paraná soils under successive cropping and potassium fertilization. Semina: Ciências Agrárias, Londrina, v. 36, n. 6, p. 4083-4098, 2015. https://doi.org/10.5433/1679-0359.2015v36n6Sup12p4083

STEINER, F.; LANA, M. C. Contribution of non-exchangeable K in soils from Southern Brazil under potassium fertilization and successive cropping. Revista Ciência Agronômica, Fortaleza, v. 49, n. 4, p. 547-557, 2018. https://doi.org/10.5935/1806-6690.20180062

TEIXEIRA, P. C.; DONAGEMMA, G. K.; FONTANA, A.; TEIXEIRA, W. G. Manual de métodos de análise de solo. $3^{\text {a }}$ Ed. Brasília, DF: EMBRAPA, 2017, 573p.

VELDE, B.; PECK, T. Clay minerals changes in the Morrow experimental plots, University of Illinois. Clays and Clay Minerals, Scotland, v. 50, n. 3, p. 364-370, 2002. https://doi.org/10.1346/000986002760833738

VIEIRA, M. S.; OLIVEIRA, F. H. T.; SANTOS, H. C.; MEDEIROS, J. S. Contribution of non-exchangeable potassium forms and its accumulation in corn plants. Revista Brasileira de Engenharia Agrícola e Ambiental, Campina Grande, v. 20, n. 1, p. 9-15, 2016. https://dx.doi.org/10.1590/18071929/agriambi.v20n1p9-15 